\title{
Legal Discourse: The Spirit of Democracy and Human Rights Post Simultaneous Regional Elections 2020 in the Covid-19 Pandemic Era
}

\author{
Fathul Hamdani \\ Faculty of Law, Universitas Mataram, Mataram, West Nusa Tenggara, Indonesia \\ Email: fhmdnny@gmail.com \\ ORCID Link: https://orcid.org/0000-0001-6988-2249
}

\author{
Ana Fauzia \\ Faculty of Law, Universitas Muhammadiyah Malang, Malang, East Java, Indonesia
}

\section{Citation:}

Hamdani, F. \& Fauzia, A. (2021). Legal Discourse: The Spirit of Democracy and Human Rights Post Simultaneous Regional Elections 2020 in the Covid-19 Pandemic Era, Lex Scientia Law Review, 5(1), 97118, doi: https://doi.org/10.15 294/lesrev.v5i1.45887

\section{History of Article}

Received: March 20, 2021

Revised: May 21, 2021

Accepted: May 27, 2021

(C) The Author(s)

\section{(c) (i) (2) (2)}

This work is licensed under a Creative Commons Attribution-NonCommercialShareAlike 4.0 International License. All writings published in this journal are personal views of the authors and do not represent the views of this journal and the author's affiliated institutions.

Lex Scientia Law Review published by Faculty of Law, Universitas Negeri Semarang, Indonesia in collaboration of UKM Lex Scientia. Published biannually every May and November.

\begin{abstract}
The implementation of these simultaneous regional elections is certainly a separate discourse that is interesting to be learned, especially concerning the enforcement of democracy and human rights. The main objectives of this research focus on the analysis related to the relationship between democracy and human rights, the fundamental dignity of democracy and human rights after the implementation of the regional leader's elections in 2020, and also the government's responsibility in case of an increase in cases of Covid-19 resulting from the implementation of simultaneous regional elections. In this research, the method used is normative juridical using statutory, conceptual, and historical approaches. The research results centered on a conception of democracy and human rights as a conception of humanity born from the history of human civilization. This conception of human rights and democracy in its development is significantly related to the conception of state law. Thus, the existence of Indonesia as a legal state places the law as a hierarchicalunity of the legal norms that culminate in the constitution, and the constitution has clearly and clearly stated in Article 28I paragraph (4) of the Constitution that: "The protection, promotion, enforcement, and fulfillment of
\end{abstract}


human rights is the responsibility of the state, especially the government." Therefore, the state is responsible for ensuring the enforcement of the human rights of citizens, especially after the implementation of the 2020 regional leader elections (hereinafter as pilkada) amid the Covid-19 pandemic era.

\section{KEYWORDS}

Covid-19 Pandemic; Democracy and Human Rights; Regional Elections

\section{INTRODUCTION}

The government policy related to the simultaneous regional elections was marked by many pros and cons in the community, which was finally held on December 9, 2020. The United States, which was also a country affected by Covid-19 on November 3, 2020, also continued to hold a democratic party even though the spread of Covid-19 had not yet slipped. The condition of America, which has the status of the highest Covid-19 affected country but still carries out the General Election, has finally become a reference for developing countries, including Indonesia. However, of course, it becomes a question whether the United States can be used as a reference for Indonesia to continue to carry out regional elections simultaneously, especially in terms of readiness. Like neighbouring Malaysia, which actually postponed the bylaws, which were initially held on December 5, 2020. Apart from that, the simultaneous regional elections did seem forced at first. Whereas if we look at the provisions in Article 201A paragraph (3), which states: "In the event that simultaneous voting as referred to in paragraph 121 cannot be implemented, simultaneous voting is postponed and rescheduled immediately after the non-natural disaster as referred to in paragraph (1) ends, through the mechanism as referred to in Article 122A."

It should be noted that the regional elections were postponed until December 9 due to a non-natural disaster. However, the simultaneous regional elections on December 9, 2020, were, in fact, held when the nonnatural disaster (Covid-19 Pandemic) had not ended. Then, if we pay close attention to the phrase "In the event that simultaneous voting as referred to in paragraph 121 cannot be implemented" in Article 210A paragraph (3) above, the sound of the phrase actually provides room for the postponement of the simultaneous regional elections again. As explained in the explanation of Article 210A paragraph (3), it states that: "The simultaneous voting in December 2020 is postponed and rescheduled if it cannot be implemented 
because the national disaster of the Corona Virus Disease 2019 (COVID-19) pandemic has not ended.

By looking at the explanation of Article 210A paragraph (3), of course, it is very clearly stated that the regional elections are simultaneously postponed and rescheduled if they cannot be implemented because the national disaster of the Covid-19 pandemic has not ended. So, the question is, has the Covid-19 pandemic national disaster ended at the time of the simultaneous regional elections on December 9, 2020? Certainly not. It is evidenced by the number of positive patients with Covid-19 who have not shown a decrease. As data obtained from the Covid-19 Handling Task Force to Kompas.com reporters on December 4-5, 2020, there were 6,027 new cases. Of course, the number of cases continues to show an increase compared to previous dates, ${ }^{1}$ Therefore, the sound of this article is then impressed only as a mere form of formal morality, and the government can continue to carry out regional elections simultaneously even though positive cases of Covid-19 have even continued to increase.

However, some essential things that need to be discussed when the simultaneous regional elections have been completed are how to follow up or the responsibility of the state, especially the government, in the event of a spike in Covid-19 cases. Given that the simultaneous regional elections in the midst of the Covid-19 pandemic this time seem to be a betting arena between democracy and human rights. Based on data on the accelerated handling of Covid-19 in Indonesia on December 17, 2020, accessed via BBC.Com, the total positive cases increased by 7,354 compared to December 16,2020 . So that the total positive cases of Covid-19 became 643,508 cases, while for those who died were 19,390 people. Furthermore, those who had recovered were 526,979 people. ${ }^{2}$

By seeing the increase in Covid-19 cases due to the 2020 simultaneous regional elections, it would certainly be interesting to discuss how the spirit of democracy and human rights was held after the simultaneous regional elections in Indonesia. Especially by seeing Indonesia as a state of the law as referred to in Article 1 paragraph (3) of the 1945 Constitution of the Republic of Indonesia, that law is not intended only to guarantee the interests of a few

\footnotetext{
${ }^{1}$ Devina Halim, "Pilkada Semakin Dekat dan Bayang-bayang Peningkatan Kasus Covid-19", Kompas Online, 6 December 2020, from https://nasional.kompas.com/read/2020/12/06/09165751/pilkada-semakin-dekat-dan-bayang-bayangpeningkatan-kasus-covid-19?amp=1\&page $=2$.

2 BBC.Com, "Pilkada: Klaster virus corona merebak setelah pemilihan kepala daerah, ahli sebut 'akibat penelusuran kontak yang lemah'", BBC Online, 18 December 2020, accessed from https://www.bbc.com/indonesia/indonesia-55321183.
} 
people in power, but to guarantee the interests of justice for all people. Thus, the rule of law being developed is not absolute rechtsstaat, but democratische rechtsstaat. ${ }^{3}$ The spirit of democracy and human rights after the 2020 simultaneous regional elections is a hotly debated study considering that the conception of democracy and human rights is born out of the same spirit, namely the spirit of humanity.4Therefore, when the two principles, namely democracy and human rights, are born with the same conception, then the process of implementing democracy should also pay attention to the protection of human rights.

Apart from that, in measuring the spirit of democracy and human rights after the 2020 regional elections simultaneously, we must not escape the series of implementing the Pilkada from start to finish. How are the problems that arise, either directly or indirectly, which significantly affect the spirit of democracy and human rights themselves? In this case, can people now determine their choice according to their conscience without any intervention from other parties? Then to what extent is the follow-up and responsibility of the government as a policymaker in the event of an increase in Covid-19 cases. Because as mandated by the constitution, all kinds of protection and promotion of human rights are the state's responsibility, especially the government.

\section{METHOD}

In this study, the method used is normative juridical using statutory, conceptual, and historical approaches. The statutory approach to legislation in question is all forms of legislation related to regional head elections, regulations related to Covid-19, and regulations pertaining to human rights in Indonesia. Then in a conceptual framework, the author examines the concepts and principles in upholding democracy and human rights. Meanwhile, in the historical approach, the author provides analysis and analysis by examining the journey of democracy and human rights as a unit in the concept of a modern rule of law.

\footnotetext{
${ }^{3}$ Jimly Asshiddiqie, Konstitusi \& Konstitusionalisme Indonesia, Revised Edition, Constitution Press, Jakarta, 2005, p. 152-162.

${ }^{4}$ Jimly Asshiddiqie, Demokrasi dan Hak Asasi Manusia, (paper presented in the general studium at The 1st National Conference Corporate Forum for Community Development, Jakarta, December 19, 2005), p. 1.
} 


\section{RESULT AND DISCUSSION}

\section{A. The Relationship between Democracy and Human Rights}

In an interview published on Prisma 7, August 1978, Herbert Feith, author of the book "The Decline of Constitutional Democracy in Indonesia," stated that democracy is a word with various interpretations. II can be seen from the various limitations or definitions of the word democracy itself. In a nominal sense, taking into account the word's origin, the word democracy is a combination of Greek words: demos (people) and kratos (government). Democracy means "government by the people."6

Meanwhile, in the dictionary, democracy is defined as "government by the people in which the supreme power rests in the hands of the people and is exercised directly by the people or their elected representatives under the free election system."7In such a definition, it appears to be a reflection of the existence of the concept of the sovereignty of the people. In a normative understanding, democracy is something that would ideally be done or implemented by a country, as, for example, revealed in Abraham Lincoln's statement that democracy is a "government of the people, by the people, and for the people." From this statement, it can be stated that democracy is built on two principles, namely self-government and the stipulation or making of laws directly by the people. ${ }^{8}$

Thus, philosophically, the presence of the rule of law has a significant role in protecting the sovereignty of the people and state sovereignty. It is then reinforced by the terminology of people's sovereignty which refers to the highest power in the people as expressed by John Locke. The formation of the people's state plays a role in forming a unified state through a pactum unionis and a pactum subjectionis. ${ }^{9}$ An agreement between citizens and the state called pactum unionis and pactum subjectionis creates maximum protection and protection for the people's interests. The birth of the people's sovereignty as the supreme of authority is based on a principle which reads solus populous supreme lex, the interests of the people are the highest law.

\footnotetext{
${ }^{5}$ Herbert Feith, Demokrasi: Tantangan Tanpa Akhir, in Dialogue, Prisma 7, August 1978, p. 45.

${ }^{6}$ Georg Sorensen, "Demokrasi dan Demokratisasi: Proses dan Prospek dalam Sebuah Dunia yang Sedang Berubah, Pustaka Pelajar, Yogyakarta, 2014, p. 2.

${ }^{7}$ Diane Ravicth, What Is Democracy?, translated by Budi Pyaritno, United States Information Agency, America, 1991, p. 4.

8 Pierre Rosalvallon, "The History of the Word Democracy in France", Journal of Democracy, Volume 6 Number 4, 1995, p. 140.

9 Mariam Darus Badrulzaman, "Hak-Hak Azazi Manusia Menurut Undang-Undang Dasar 1945 dan Penjabarannya di dalam hukum Perjanjian Nasional", Jurnal Hukum dan Pembangunan, Volume 11, Number 1, 1981, p. 16.
} 
The manifestation of protection of the people's interests is further regulated in detail in the form of protection, promotion, enforcement and fulfillment of human rights and rights of citizens in the constitution of the Indonesian nation. So that in the implementation of democracy, it should pay attention to the interests of the people as a whole as mandated by the constitution, one of which is related to the protection of human rights and the rights of citizens. The basis for the existence of a constitution is a general agreement or agreement (consensus) among the majority of the people regarding the idealized building concerning the state. The constitution is a joint consensus or general understanding of all citizens. ${ }^{10}$ The most fundamental interest of every citizen is the protection of his rights as a human being.

The idea of human rights has grown in line with the development of democracy, especially with the victory of democratic countries against fascist countries in World War II. In 1948 the United Nations ratified the Universal Declaration of Human Rights, with the approval of 48 countries even though eight countries abstained, among others: the Soviet Union, Saudi Arabia, and South Africa. Although the Declaration of Human Rights is not legally binding, it remains the minimum guideline and standard that all human beings aspire to. ${ }^{11}$ Therefore, it can be understood that democracy and human rights are conceptions of humanity and social relations that were born from the history of human civilization in all corners of the world. Human rights and democracy can also be interpreted as the result of human struggles to maintain and achieve human dignity. Until now, only the conceptions of human rights and democracy have been proven to most recognize and guarantee the dignity of humanity.

The implementation of the concept of human rights and democracy concerning the assurance of human dignity is reflected in the mechanism for implementing democracy which not only emphasizes the importance of protecting the voting rights of citizens but the essential thing in the process of upholding human rights is the importance of protecting public health rights, and the right to security in any democratic procedure.

\footnotetext{
${ }^{10}$ William G. Andrews, for example, in his book Constitutions and Constitutionalism 3rd edition, states: "The members of a political community have, by definition, common interests which they seek to promote or protect through the creation and use of the compulsory political mechanisms we call. The State", Van Nostrand Company, New Jersey, 1968, p. 9.

${ }^{11}$ Ellya Rosana, "Negara Demokrasi dan Hak Asasi Manusia", Jurnal TAPIs, Volume 12, Number 1, 2016, p. 49.
} 


\section{B. The spirit of Democracy and Human Rights after the 2020 Simultaneous Regional Elections}

General elections and regional head elections are a means to facilitate the process of struggling for the people's mandate to gain power. In elections, the people as holders of state sovereignty have the right to elect a leader who will determine the government's fate for the next five years. ${ }^{12}$ The democratic party to elect regional heads and deputy regional heads, which was initially postponed, was finally completed on December 9, 2020. Democracy must continue to be carried out, but the implementation of democracy must not escape the safeguarding of human rights and the rights of citizens, especially concerning public health rights. Health rights are human rights, which arise because of democratization, ${ }^{13}$ So it seems less beautiful if the right to health is sacrificed in the name of democracy, considering that democracy and human rights are two concepts that do not negate each other. However, what is interesting is how is the spirit of democracy and human rights after the 2020 simultaneous regional elections?

The spirit of democracy and human rights after the simultaneous regional elections 2020 are, of course, directly proportional to the simultaneous regional election implementation process and the output produced in the simultaneous regional elections, both in terms of the resulting leaders and in terms of protecting the human rights of citizens. According to Eklit and Reynolds as well as the Social Economic Information Education Research Institute (LP3S) that there are several indicators in measuring the quality of elections/Pilkada including, the quality of organizers, quality candidates, fair and clean campaigns, and the output produced in the implementation of these elections. ${ }^{4}$ Therefore, in the context of the simultaneous regional elections in the Covid-19 pandemic era, according to the above indicators, according to the author, several things that deserve to be used as indicators in measuring the morale of democracy and human rights in the post-2020 simultaneous regional elections can be described, namely: First, related to Anticipatory steps taken by the government in regulating the Pilkada implementation strategy during the pandemic as an effort to detect a

\footnotetext{
${ }^{12}$ M. Zaid Wahyudi, "Menjaga Pemilu tetap Luber Jurdil", Kompas Daily, March 10, 2009, p. 7.

${ }^{13}$ Bobi Aswandi and Kholis Roisah, "Negara Hukum dan Demokrasi Pancasila dalam Kaitannya dengan Hak Asasi Manusia (Ham)", Jurnal Pembangunan Hukum Indonesia, Volume 1, Number 1, 2019, p. 128-145.

${ }^{14}$ Lati Praja Delmana, Aidinil Zetra, \& Alfan Miko, "Indonesian Election Quality Assessment in Realizing Quality Elections", Journal of Governance and Political Social UMA, Volume 7, Number 1, 2019, p. 61.
} 
spike in positive cases of Covid-19, secondly, the compliance of candidates and the public in implementing health protocols, and third, whether or not the practice of money politics was present during the simultaneous preimplementation of regional elections as well as during the simultaneous regional elections.

The indicators referred to above refer to the election quality indicators in connection with the first indicator, as a comparison, namely by looking at the readiness for the implementation of elections conducted in the United States with the implementation of the elections in Indonesia. To deal with the potential transmission of Covid-19, America has not only emphasized the importance of adhering to health protocols during election time. Still, it has also put in place systems to avoid crowds. The United States Electoral College administers the electoral system in person and by mail (voting by mail). Direct elections were held on November 3, 2020, while voters by post were sent ballots starting mid-September 2020. As for Indonesia, There is no new system to anticipate the fluctuation of the increase in Covid-19 cases implemented by the government, apart from only adhering to health protocols. In fact, until now, especially in rural areas, many people do not believe in the existence of Covid-19. For example, according to a survey by the Bogor Health Office, only 15 percent of the population believed in Covid-19, so health protocols would be straightforward to break.

In addition, even though the elections in Indonesia and the elections in America were both held during the Covid-19 pandemic, it should be underlined that Indonesians are sceptical of the government because they are considered to have certain objectives in the implementation of the 2020 Pilkada. Meanwhile, Americans make the 2020 Election momentum for people's resistance to Donald Trump's trivial attitude and failure to deal with the Covid-19 pandemic. With the 2020 General Election implementation, Americans hope to be a transitional period towards better conditions in their country. Not without reason, given the attitude of the Indonesian government, which insists on carrying out the 2020 Pilkada simultaneously, which has led to public speculation regarding the interests of the government's elite political dynasty. As the data obtained from the findings of the Nagara Institute, where there are 124 regional head candidates affiliated with political dynasties and running for regional heads, consisting of 57 candidates for regents and 30 candidates for deputy regents, 20 candidates for mayor, and eight candidates for deputy mayor, as well as five candidates for governor and four candidates for deputy governor. Then by looking at the results of a survey conducted by the Charta Politika Institute, which measures the readiness of the community if the 2020 regional elections are still held, the result is that the majority of the people disagree, namely $54.2 \%$ disagree, 
$31.8 \%$ agree, and 14, 1\% did not answer. Then by looking at the results of a survey conducted by the Charta Politika Institute, which measures the readiness of the community if the 2020 regional elections are still held, the result is that the majority of the people disagree, namely $54.2 \%$ disagree, $31.8 \%$ agree, and $14,1 \%$ did not answer. ${ }^{15}$ Meanwhile, in another survey conducted by the Indicator Institute, $63.1 \%$ stated that the Pilkada on December 9, 2020, should be postponed, while only $34.3 \%$ of respondents stated that the simultaneous regional elections would still be held. ${ }^{16}$

The second indicator is related to the level of health protocol violations, that based on data released by Bawaslu RI, ${ }^{17}$ that the number of health protocol violations during the 2020 Pilkada campaign continued to increase, namely as many as 375 cases in the period 6-15 October. This number increased when compared to the cases of violation of the health protocol that occurred ten days earlier, namely 237 cases, between September 26 to October 5 2020.The number of violations of health protocols during the implementation of the campaign was certainly not the fault of the candidate pairs, but also the mistakes of regional head and deputy regional candidates for not following the procedures for implementing the campaign during the Covid-19 pandemic. In addition, based on a report submitted by Bawaslu Commissioner Fritz Edward Siregar, there were 316 regional head candidates who violated the Covid-19 health protocol when registering themselves. These violations occurred in 243 regions out of 270 regions holding simultaneous regional elections in $2020 .{ }^{18}$ The practice of money politics also exacerbates problems related to health protocol violations by regional candidate pairs and deputy regional heads. Based on data submitted by Ratna Dewi Pettalolo, member of the Election Supervisory Agency for the Election Division, stated that there were 205 cases of money politics up to the voting

${ }^{15}$ Elza Astari Retaduari, "Survei Charta Politika: Hanya 34,9\% Pemilih Pilkada Siap ke TPS", Detik Online, July 22, 2020, accessed from https://news.detik.com/berita/d-5104353/ survei-charta-politikahanya-349-pemilih-pilkada-siap-ke-tps.

${ }^{16}$ Dani Prabowo, "Hasil Dua Survei, Masyarakat Berharap Pilkada Serentak 2020 Ditunda", Kompas Online, July 23, 2020, from https://amp.kompas.com/nasional/read/2020/2020/07/23/09444091/hasil-dua-survei-masyarakatberharap-pilkada-serentak-2020-ditunda\#aoh=16114649328430\&referrer=https\%3A\% $\quad 2 \mathrm{~F} \%$ 2Fwww.google.com \& amp_tf $=$ From $\% 20 \% 251 \% 24 s$.

${ }^{17}$ Dani Prabowo, "Kasus Covid-19 Meningkat di Tengah Perhelatan Pilkada serentak", Kompas Online, October 19, 2020, accessed from https://nasional.kompas.com/read/2020/10/19/14470911/kasuscovid-19-menaikan-di-tengah-perhelatan-pilkada-serentak?page=all.

${ }^{18}$ Nicky Aulia Widadio, "316 Bakal Paslon Kepala Daerah Langgar Protokol Kesehatan Covid-19", aa.comOnline, September 7, 2020, accessed from https://www.aa.com.tr/en/nasional/316-bakalpaslon-kepala-daerah-langgar-protokol-kkes-covid-19/1965019. 
day in the regional head and deputy regional head elections. Of the total, 109 cases were based on public reports, and 96 were the findings of Bawaslu. ${ }^{19}$

As stated by the Chairman of the Network for Indonesian Democratic Society, Dahlia Umar, although the practice of money politics has existed for a long time, the simultaneous regional elections were held amidst the limitations of regional candidate pairs and deputy regional heads to introduce themselves to the community and socialize themselves to the community through campaigns. The more perpetuating the practice of money politics. ${ }^{20}$ With these limitations, the practice of money politics is considered the best shortcut to gain public support. ${ }^{21}$ If money politics violations have occurred repeatedly and are cultured in every election period or regional election, if they continue to be ignored, then the aspiration to get leaders who are honest, fair with integrity, and work for the people will be difficult to achieve because these leaders were born in different ways, which is not justified..$^{22}$

In the implementation of the 2015 Pilkada, based on the Data on the Handling of Money Politics Violations obtained from the Bawaslu.go.id website, there were 204 total money political crime violations spread across 16 Provinces in Indonesia. ${ }^{23}$ Although this figure is not much different from the 2020 simultaneous regional elections, at the time of the 2020 simultaneous regional elections, there is no final data related to money political crime violations, and there is still potential for additional either based on findings from Bawaslu or reports from the public. In addition, by considering the conditions that affect the level of money politics in the community between before the pandemic and during the pandemic, at least money politics can be suppressed if there is no Covid-19 pandemic which is caused by encouragement from economic factors and others.

Actions of this kind will damage the integrity of the Pilkada itself. The integrity of the implementation of this Pilkada will certainly affect the spirit of democracy as well. Norris, in his book, explains the importance of the

\footnotetext{
19Jaffry Prabu Prakoso, "Bawaslu Catat 205 Kasus Politik Uang di Pilkada 2020", Bisnis Online, December 9, 2020, accessed from https://m.bisnis.com/amp/read/20201209/15/1328701/bawaslucatat-205-kasus-politik-uang-di-pilkada-2020.

${ }^{20}$ Lombok Post, "Kasus Politik Uang di Pilkada Melonjak", Lombok Post Online, October 20, 2020, accessed from https://lombokpost.jawapos.com/nasional/20/10/2020/kasus-politik-uang-di-pilkadamelonjak/.

${ }^{21}$ Liza Tambunan, “Pilkada: Bawaslu Sebut Pandemi Covid-19 Membuat Politik Uang 'Meningkat'”, BBC Online, December 9, 2020, accessed from https://www.bbc.com/indonesia/indonesia-55240008.

${ }^{22}$ Nisa Nabila, Paramita Prananingtyas, dan Muhamad Azhar, "Pengaruh Money Politic dalam Pemilihan Anggota Legislatif terhadap Keberlangsungan Demokrasi di Indonesia", Jurnal Notarius, Volume 13, Number 1, 2020, p. 4.

23Badan Pengawas Pemilu, "Data Penanganan Pelanggaran Politik Uang Pilkada 2015 dan 2017", Bawaslu Online, July 12, 2017, accessed from https://www.bawaslu.go.id/id/hasil-pengawaspemilu/data-panganan-pelanggaran-politik-uang-pilkada-2015-dan-2017.
} 
integrity of elections/Pilkada for various aspects, such as legitimacy, because through elections with integrity, public trust will be built in multiple political institutions. ${ }^{24}$ In a broader sense, public trust in various political institutions greatly determines how the spirit of democracy in a country is, because the lower public trust in political institutions, the lower the quality of democracy. Given that the democratic process is an embodiment of the thoughts, voices, and conscience of the people.

Thus, although the practice of money politics is a practice that has been around for a long time, amid the limited implementation of simultaneous regional elections, the public is unable to get to know their candidates for regional leaders because of limited campaign performances. In fact, the campaign has a very significant role and is an organized effort that seeks to influence someone to make decisions to make choices. ${ }^{25}$ However, due to the unfinished condition of the Covid-19 pandemic, the campaign implementation cannot be carried out thoroughly and optimally. So that this condition has increasingly triggered the practice of money politics, especially during the condition of the community which is being crushed by economic problems due to the Covid-19 pandemic. Besides the term money politics, it is also known as vote-buying. Literally, vote-buying is a simple monetary exchange. Candidates buy, and citizens sell votes. Vote-buying can also be interpreted as providing money or other benefits to voters to support certain candidates or to election organizers as an incentive to manipulate election results. ${ }^{26}$

Apart from having an impact on the quality of the leaders produced, these practices also undermine the dignity of the people. The candidates for a regional head who give a sum of money in the hope that the people who convict them will elect them when the election takes place, is a form of violation of human rights. This is stated in Article 28E paragraph (2) of the 1945 Constitution of the Republic of Indonesia, which reads: "Everyone has the right to freedom of belief, to express thoughts and attitudes, according to their conscience". Finally, they have to choose candidates on the basis that they have received money from the candidates and because of gratitude to candidates

\footnotetext{
${ }^{24}$ Mudiyati Rahmatunnisa, "Mengapa Integritas Pemilu Penting?", Jurnal Bawaslu, Volume 3 Number 1, 2017, p. 6.

${ }^{25}$ Ratna Dewi Indrayanti, "Kampanye sebagai Komunikasi Politik: Peran Tingkat Pendidikan Seseorang dalam Menyikapi Kampanye Ditinjau dari Etika dan Pendidikan Politik", OSFOnline, July 1, 2019, accessed from https://osf.io/kyxgc/download/?format=pdf.

${ }^{26} \mathrm{M}$. Jeffri Arlinandes Chandra dan Jamaludin Ghafur, "Peranan Hukum dalam Mencegah Praktik Politik Uang (Money Politics) dalam Pemilu di Indonesia: Upaya Mewujudkan Pemilu yang Berintegritas", Jurnal Wajah Hukum,Volume 4 Number 1, 2020, p. 55.
} 
who have helped them in fulfilling their daily needs, not on the basis of conscience and rational judgment.

Therefore, to see the extent to which the spirit of democracy and human rights is preserved and defended, it is not enough just to be seen by using a point of view that the regional elections have been completed. However, by looking at how the process and the resulting output. During the process of implementing the Pilkada all the principles in effect had been carried out successfully or not. Did the consequential leaders have good integrity and capability or not, and whether at the time of the Pilkada there were no human rights or human rights of citizens who are sacrificed.

Furthermore, as expressed by political expert LIPI, Syarip Hidayat in the National Seminar "End of Year Reflections: Achievements of Indonesia's Democracy Index and Simultaneous Regional Election Evaluation $2020^{\prime \prime},{ }^{27}$ whereas in terms of quantity, the institutions and rules of the democratic game have been presented, in terms of quality, the ongoing practice has not yet reflected the character of substantive democracy, due to lack of capacity. In this case, elections tend to function more as an instrument by political elites to gain community legitimacy. So, the implication is that the votes mandated by the community will not have an impact on improving policies in the administration of government in the post-election period.

So, in this case, as a reflection of the various kinds of polemics that occur in every election and regional election, such as golput, the practice of money politics, the weak integrity of the election/Pilkada implementation, and other problems, it can only be corrected by improving the people first. A good system without good humans, the system will never work properly. Thus, the position of law as an instrument for regulating people's lives, as a tool for engineering the social life of the community, has an important role in building a society's culture that is aware of democracy. ${ }^{28}$ The role of law as a tool of social control and tool of social engineering can basically be used as a theoretical basis for the government in taking every policy for the sake of development and legal reform in Indonesia, especially about improving the legal culture of government officials and society so that they can carry out election principles/Pilkada properly and aware of their rights and obligations, to achieve the life of the people they aspire to.

\footnotetext{
${ }^{27}$ Okezone Team, "Pasca-Pilkada 2020, Demokrasi di Indonesia, Dinilai Tak Substantif", Okezone Online, December 17, 2020, accessed from https://nasional.okezone.com/read/2020/12/17/337/2329603/pasca-pilkada-2020-demokrasi-diindonesia-dinilai-tak-substantif.

${ }^{28}$ Munir Fuady, Teori-Teori Besar dalam Hukum, Prenada media Group, Jakarta, 2013, p. 249.
} 


\section{The Government's Responsibility in the Event of an Increase in Covid-19 Cases}

The existence of a relationship between the state and citizens creates certain obligations that must be fulfilled by the state. So that it is the state's obligation to protect and serve its citizens. The obligations that arise as a consequence of the relationship between the state and citizens are very broad and varied, one of which is the legal obligation that occurs because of human rights claims. The government essentially carries out the objectives and functions of the state in relation to citizens as the personified legal entity of the state. ${ }^{29}$ This is then emphasized in Article 28I paragraph (4) of the 1945 Constitution of the Republic of Indonesia that: "Protection, advancement, enforcement and fulfilment of human rights are the responsibility of the state, especially the government". In a narrower sense, the protection, promotion, enforcement, and fulfilment of human rights are related to citizens' right to health.

Besides, based on the formulations in the Universal Declaration of Human Rights, the International Covenant on Civil and Political Rights, and the International Covenant on Economic, Social and Cultural Rights, which constitute state recognition of human rights as the substance of the three instruments. This then creates consequences for the state to protect and promote human rights, ${ }^{30}$ which relates to the protection and advancement of citizens' health rights.

By seeing the spike in Covid-19 cases after the 2020 simultaneous regional elections, of course, this will further strengthen the responsibility of the state, especially the government. Mainly when the spike in Covid-19 cases was caused by policies taken by the government, which seemed hasty in implementing simultaneous regional elections. Sugeng Istanto gave an understanding of state responsibility by using the term state responsibility. According to him, state accountability is the state's obligation to provide an answer that calculates something that has happened and an obligation to provide recovery for any losses that may be incurred. ${ }^{31}$ Therefore, the increase in Covid-19 cases after the simultaneous regional elections must be responded to and handled by the government as soon as possible. This is because there is a consensus in the Indonesian constitution that the right to health is a

\footnotetext{
${ }^{29}$ Sartika Sasmi Ticoalu, "Tanggung Jawab Pemerintah dalam Memberikan Pelayanan Kesehatan terhadap Masyarakat", Jurnal Lex et Societatis, Volume 1, Number 5, 2013, p. 155.

${ }^{30}$ Jimly Asshiddiqie, "Konstitusi dan Hak Asasi Manusia", (makalah disampaikan pada Lecture Peringatan 10 Tahun Kontras. Jakarta, 26 Maret 2008), p. 22.

${ }^{31} \mathrm{~F}$. Sugeng Istanto, Hukum Internasional, Universitas Atma Jaya, Yogyakarta, 1994, p. 105.
} 
fundamental right for humans. ${ }^{32}$ The basic philosophy of guaranteeing the right to health as human rights is the raison d'etre of human dignity. ${ }^{33} \mathrm{Health}$ is a fundamental right of every human being. Therefore, every individual, family, and community have the right to obtain protection for their health, and the government is responsible for regulating and protecting the community so that their health rights are fulfilled so that they are immediately free from Covid-19.

The government can do the first thing in response to the spike in Covid19 cases to ensure the availability of health service facilities. The 1945 Constitution of the Republic of Indonesia, Article 34 paragraph (3) emphasizes that: "The state is responsible for the provision of health service facilities...". So that in this case, the constitution has actually mandated that the provision of health facilities is the responsibility of the state, and the state is also responsible for ensuring that the public can reach these health service facilities. The insurance for this health service also includes, among others, the provision of adequate treatment rooms to quarantine places for positive Covid-19 patients.

In addition, Mac Iver in his book entitled "Web of Government" suggests that one of the functions of the state in terms of transformation is the public welfare function, which includes the maintenance of people's health and the care of material spiritual well-being. ${ }^{34}$ The functions of maintaining the health and welfare of the community are of course, two things that must always be integrated. As a follow-up to the government for the spike in Covid-19 cases after the 2020 simultaneous regional elections, the government must optimize the role of inter-ministerial agencies, for example, the Ministry of Social Affairs and the Ministry of Health, in formulating policy formulations.

If so far, social assistance and other policies are still evenly distributed to all people, both directly and indirectly affected by Covid-19, then another policy that can be taken is to prioritize social assistance to victims of positive cases of Covid-19 with a lower-middle economic level. In addition, injections of funds, either directly or indirectly, to MSMEs and other small businesses must also continue and be on target. Because considering the social assistance that has been provided to the community is often not on target. As an

\footnotetext{
${ }^{32}$ Fheriyal Sri Isriawaty, "Tanggung Jawab Negara dalam Pemenuhan Hak atas Kesehatan Masyarakat Berdasarkan Undang-Undang Dasar Negara Republik Indonesia Tahun 1945", Jurnal Ilmu Hukum Legal Opinion, Volume 3, Number 2, 2015, p. 3.

${ }^{33}$ Majda El Muhtaj, Dimensi-Dimensi HAM: Mengurai Hak Ekonomi, Sosial, dan Budaya, Rajawali Pers, Jakarta, 2008, p. 152.

${ }^{34}$ I Dewa Gede Atmadja, Ilmu Negara: Sejarah, Konsep Negara, dan Kajian Kenegaraan, Setara Press, Malang, 2015, p. 57.
} 
example, The Lampung Ombudsman, for example, received complaints from people who felt they were included in the conditions for receiving assistance but were not recorded. As many as 20 households registered as recipients of social assistance in North Bekasi did not receive any assistance at all. In fact, social assistance is given to people who are well off, for example it is given to residents who have four-wheeled vehicles and more than one, and there are many other cases. ${ }^{35}$

Based on the results of a national survey related to social assistance, out of 1,235 respondents, $96 \%$ of them knew about social assistance in the form of distribution of necessities, PKH (Conditional Cash Transfer Programme), and BLT (Direct Cash Assistance) for underprivileged residents. As many as $49 \%$ of respondents stated that the assistance program was less/not on target, and as many as $37 \%$ of respondents said that the assistance program was right on target. ${ }^{36}$ Meanwhile, the results of other studies show that social assistance has not reached all vulnerable communities. ${ }^{37}$ Therefore, it is necessary to strengthen its coordination from the central government to the village government. Then the relevant ministries/agencies must coordinate and update data on the poor (who must receive assistance) due to being affected by Covid-19. Then the government must provide strict sanctions if violations are found in the field by government officials.

In its implementation, so that social assistance can run optimally, it is necessary to have supervision. The social assistance policy is the same as other policies made by the government that must be monitored both internally and externally, this is based on reason that the government as a state organization assigned the task of administering government must be able to be responsible for its actions before the law. Furthermore, according to Martosoewignjo, supervision is one of the elements of a rule of law in which every element in a country is subject to and bound to the law, which becomes a collective agreement. ${ }^{38}$ Based on this understanding, the social assistance policy is a legal product made and implemented by the government so that it must be

\footnotetext{
35International Association for Public Participation, "Dinamika Bantuan sosial, Lagu Lama atau Lagu Baru?", IAP Online, May 21, 2020, accessed from https://iap2.or.id/dinamika- social assistance-oldsongs-or-new-songs /.

${ }^{36}$ Saiful Mujani, "Wabah Covid-19: Efektivitas Bantuan Sosial", Online, May 6, 2020, accessed from https://saifulmujani.com/wp-content/uploads/2020/05/0512-Riliscovid-12-mei-FINAL.pdf.

${ }^{37}$ Mohammad Teja, "Permasalahan Keakuratan Data Penerima Bantuan Sosial Covid-19", Kajian Singkat terhadap Isu Aktual dan Strategis, Pusat Penelitian Badan Keahlian DPR RI, Volume 12, Number 18, 2020, p. 16.

${ }^{38}$ Sri Soemantri Martosoewignjo, Bunga Rampai Hukum Tata Negara Indonesia, Alumni, Bandung, 1992, p. 22.
} 
accounted for in front of the law. In practice, supervision is divided into several types, namely: First, internal supervision, which is a form of supervision carried out by elements or units from within the organization itself or being part of government organizations in general. Second, external supervision, which is a form of supervision carried out by elements or units outside the organization. ${ }^{39}$

The point is that in addition to supervision that comes from internal government, there must also be supervision from the community, whether through non-governmental organizations, non-governmental organizations, and others. So, in this case, it is necessary to develop a collaborative supervision model between government agencies and non-government agencies. The supervisory model for the implementation of the social assistance policy must be based on five principles, namely: ${ }^{40} \mathrm{First}$, the cooperation of various elements/multi actors. Second, it is carried out on the basis of mutual understanding. Third, intertwined efforts in carrying out surveillance efforts. Fourth, equality between actors and synergy. Fifth, the results of monitoring are a mutual consensus. It is hoped that the application of the principles of collaborative supervision will minimize errors in determining the data for social assistance recipients. Thus, people who receive social assistance are the correct community group and receive social assistance.

\section{CONCLUSION}

Human rights and democracy in the rule of law constitute an inseparable unit and complement each other. The existence of Indonesia as a constitutional state places law as a hierarchical unit of legal norms that culminates in the constitution, and the constitution has clearly and mandated in Article 1 paragraph (2) of the 1945 Constitution of the Republic of Indonesia that the implementation of people's sovereignty must be based on the constitution. In a broader sense, the meaning of the sentence "based on the constitution" is that everything related to the people's interests regulated by the constitution, including human rights, must be used as a reference and cannot be violated. In the implementation of democracy, the rights of citizens are not only related to the right to vote but also with regard to the right to public health. The spike in positive cases of Covid-19 that occurred as a result of the simultaneous regional elections and other problems certainly affected the spirit of democracy and human rights itself. The increase in Covid-19

\footnotetext{
${ }^{39}$ Brantas, Dasar-Dasar Manajemen, Alfabeta, Jakarta, 2009, p. 95.

${ }^{40}$ Dian Herdiana, "Pengawasan Kolaboratif dalam Pelaksanaan Kebijakan Bantuan Sosial Terdampak Covid-19", Jurnal Dinamika Pemerintahan, Volume 3, Number 2, 2020, p. 98.
} 
cases due to the 2020 simultaneous regional elections must be responded to immediately with real action from the government as a form of state responsibility in guarding the enforcement of human rights, especially the health rights of citizens. The rights referred to include with respect to health insurance and people's welfare, starting from the provision of proper health facilities to social assistance to people affected by Covid-19. An effort that the government can make is to optimize the role of inter-ministerial agencies, for example, the Ministry of Social Affairs and the Ministry of Health, in formulating policies. In addition, the importance of optimizing supervision, both internally, namely a form of supervision carried out by elements or units within the organization itself or being part of a government organization in general, as well as external supervision, namely a form of supervision carried out by elements or units that are from outside the organization or nongovernment.

\section{DECLARATING OF CONFLICTING INTEREST}

None

\section{FUNDING INFORMATION}

None

\section{ACKNOWLEDGEMENT}

First of all, the authors want to thank Allah SWT. Because of His grace and charm. So that the authors can complete this article. The authors also thank the family for their support and prayers, then to our supervisors for their knowledge and learning during discussion and consultation regarding this article.

\section{REFERENCES}

Andrews, W. G. (1968). Constitutions and Constitutionalism 3rd edition. New Jersey: Van Nostrand Company.

Asshiddiqie, J. (2005). Konstitusi \& Konstitusionalisme IndonesiaEdisi Revisi. Jakarta: Konstitusi Press.

Asshiddiqie, J. (2005). "Demokrasi dan Hak Asasi Manusia". Paper presented in the general studium at The 1st National Conference Corporate Forum for Community Development. Jakarta.

Asshiddiqie, J. (2008). "Konstitusi dan Hak Asasi Manusia". Paper presented at Lecture Peringatan 10 Tahun Kontras. Jakarta. 
Aswandi, B., \& Roisah, K. (2019). Negara Hukum dan Demokrasi Pancasila dalam Kaitannya dengan Hak Asasi Manusia (Ham). Jurnal Pembangunan Hukum Indonesia, 1(1). 128-145. https://doi.org/10.14710/jphi.v1i1.128.145.

Atmadja, I. D. G. (2015). Ilmu Negara: Sejarah, Konsep Negara, dan Kajian Kenegaraan. Malang: Setara Press.

Badan Pengawas Pemilu. (July, 2017). "Data Penanganan Pelanggaran Politik Uang Pilkada 2015 dan 2017", Bawaslu Online, July 12, 2017, accessed from https://www.bawaslu.go.id/id/hasil-pengawasan-pemilu/datapenanganan-pelanggaran-politik-uang-pilkada-2015-dan-2017.

Badrulzaman, M. D. (1981). Hak-Hak Azazi Manusia Menurut UndangUndang Dasar 1945 dan Penjabarannya di dalam hukum Perjanjian Nasional. Jurnal Hukum dan Pembangunan, 11(1). 16-24. http://dx.doi.org/10.21143/jhp.vol11.no.1.837.

BBC.Com. (December, 2020). “Pilkada: Klaster virus corona merebak setelah pemilihan kepala daerah, ahli sebut 'akibat penelusuran kontak yang lemah'”, BBC Online, December 18, 2020, accessed fromhttps://www.bbc.com/indonesia/indonesia-55321183.

Brantas. (2009). Dasar-Dasar Manajemen. Jakarta: Alfabeta, 2009.

Chandra, M. J. A., \& Ghafur, J. (2020). Peranan Hukum dalam Mencegah Praktik Politik Uang (Money Politics) dalam Pemilu di Indonesia: Upaya Mewujudkan Pemilu yang Berintegritas. Jurnal Wajah Hukum, 4(1). 52-66. http://dx.doi.org/10.33087/wjh.v4i1.167.

Feith, H. (1978). "Demokrasi: Tantangan Tanpa Akhir", in the Tajuk Dialog, Prism 7.

Fuady, M. (2013). Teori-Teori Besar dalam Hukum. Jakarta: Prenadamedia Group.

Halim, D. (December, 2020). "Pilkada Semakin Dekat dan Bayang-bayang Peningkatan Kasus Covid-19", Kompas Online, December 6, 2020, accessed from https://nasional.kompas.com/read/2020/12/06/09165751/pilkadasemakin-dekat-dan-bayang-bayang-peningkatan-kasus-covid19? amp $=1$ \&page $=2$.

Herdiana, D. (2020). Pengawasan Kolaboratif dalam Pelaksanaan Kebijakan Bantuan Sosial Terdampak Covid-19. Jurnal Dinamika Pemerintahan, 3(2). 85-99.

Indonesia. (1945). Undang-Undang Dasar Negara Republik Indonesia Tahun 1945. Indonesia. (1999). Undang-Undang Hak Asasi Manusia, UU No. 39 Tahun 1999, LN No. 165 Tahun 1999, TLN No 3886.

Indonesia. (2000). Undang-Undang Pengadilan Hak Asasi Manusia, UU No. 26 Tahun 2000, LN No. 208 Tahun 2000, TLN No 3327. 
Indonesia. (2020). Perppu tentang Perubahan Ketiga atas Undang-Undang Nomor 1 Tahun 2015 tentang Penetapan Peraturan Pemerintah Pengganti Undang-Undang Nomor I Tahun 2014 tentang Pemilihan Gubernur, Bupati, dan Walikota Menjadi Undang-Undang, Perppu No.2 Tahun 2020, LN No.128 Tahun 2020, TLN No 6512.

Indrayanti, R. D. (July, 2019). “Kampanye sebagai Komunikasi Politik: Peran Tingkat Pendidikan Seseorang dalam Menyikapi Kampanye Ditinjau dari Etika dan Pendidikan Politik", OSF Online, July 1, 2019, accessed from https://osf.io/kyxgc/download/?format=pdf.

International Association for Public Participation. (May, 2020). “Dinamika Bantuan sosial, Lagu Lama atau Lagu Baru?", IAP Online, May 21, 2020, accessed from https://iap2.or.id/dinamika-bantuan sosial-lagulama-atau-lagu-baru/.

Isriawaty, F. S. (2015). Tanggung Jawab Negara dalam Pemenuhan Hak atas Kesehatan Masyarakat Berdasarkan Undang-Undang Dasar Negara Republik Indonesia Tahun 1945, Jurnal Ilmu Hukum Legal Opinion, 3. $1-9$.

Istanto, F. Sugeng. (1994). Hukum Internasional. Yogyakarta: Universitas Atma Jaya.

Lombok Post. (October, 2020). "Kasus Politik Uang di Pilkada Melonjak", Lombok Post Online, October 20, 2020, accessed from https://lombokpost.jawapos.com/nasional/20/10/2020/kasus-politikuang-di-pilkada-melonjak/.

Martosoewignjo, S. S. (1992). Bunga Rampai Hukum Tata Negara Indonesia. Bandung: Alumni.

Muhtaj, M. E. (2008). Dimensi-Dimensi HAM: Mengurai Hak Ekonomi, Sosial, dan Budaya. Jakarta: Rajawali Pers.

Mujani, S. (May, 2020). "Wabah Covid-19: Efektivitas Bantuan Sosial”, Saiful Mujani Online, May 6, 2020, accessed from https://saifulmujani.com/wp-content/uploads/2020/05/0512Riliscovid-12-mei-FINAL.pdf.

Nabila, N., Prananingtyas, P., \& Azhar, M. (2020). Pengaruh Money Politic dalam Pemilihan Anggota Legislatif terhadap Keberlangsungan Demokrasi di Indonesia, Jurnal Notarius, 13(1). 138-153.

Okezone.Com. (December, 2020). "Pasca-Pilkada 2020, Demokrasi di Indonesia, Dinilai Tak Substantif", Okezone Online, December 17, 2020, accessed from

https://nasional.okezone.com/read/2020/12/17/337/2329603/pascapilkada-2020-demokrasi-di-indonesia-dinilai-tak-substantif. 
Prabowo, D. (October, 2020). "Kasus Covid-19 Meningkat di Tengah Perhelatan Pilkada serentak", Kompas Online, October 19, 2020, accessed from https://nasional.kompas.com/read/2020/10/19/14470911/kasus-covid19-meningkat-di-tengah-perhelatan-pilkada-serentak?page=all.

Prabowo, D. (July, 2020). "Hasil Dua Survei, Masyarakat Berharap Pilkada Serentak 2020 Ditunda", Kompas Online, July 23, 2020, accessed from https://amp.kompas.com/nasional/read/2020/2020/07/23/09444091/has il-dua-survei-masyarakat-berharap-pilkada-serentak-2020ditunda\#aoh=16114649328430\&referrer=https\%3A\%2F\%2Fwww.goog le.com\&amp_tf=Dari\%20\%251\%24s.

Prakoso, J. P. (December, 2020). “Bawaslu Catat 205 Kasus Politik Uang di Pilkada 2020", Bisnis Online, December 9, 2020, accessed from https://m.bisnis.com/amp/read/20201209/15/1328701/bawaslu-catat205-kasus-politik-uang-di-pilkada-2020.

Rahmatunnisa, M. (2017). Mengapa Integritas Pemilu Penting?. Jurnal Bawaslu, 3(1). 1-11.

Ravicth, D. (1991). What Is Democracy?, terjemahan Pyaritno, Budi. Amerika: United States Information Agency.

Retaduari, E. A. (July, 2020). "Survei Charta Politika: Hanya 34,9\% Pemilih Pilkada Siap ke TPS", Detik Online, July 22, 2020, accessed from https://news.detik.com/berita/d-5104353/ survei-charta-politikahanya-349-pemilih-pilkada-siap-ke-tps.

Rosalvallon, P. (1995). The History of the Word Democracy in France", Journal of Democracy, 6(4). 140-154.

Rosana, E. (2016). Negara Demokrasi dan Hak Asasi Manusia. Jurnal TAPIs, 12(1). 37-52.

Sabine, G. H. (1961). A History of Political Theory, Third Edition. New York: Holt, Rinehart and Winston.

Sorensen, G. (2014). Demokrasi dan Demokratisasi: Proses dan Prospek dalam Sebuah Dunia yang Sedang Berubah. Yogyakarta: Pustaka Pelajar.

Tambunan, L. (December, 2020). “Pilkada: Bawaslu Sebut Pandemi Covid-19 Membuat Politik Uang 'Meningkat'”, BBC Online, December 9, 2020, accessed from https://www.bbc.com/indonesia/indonesia-55240008.

Teja, M. (2020). Permasalahan Keakuratan Data Penerima Bantuan Sosial Covid-19. Kajian Singkat terhadap Isu Aktual dan Strategis, Pusat Penelitian Badan Keahlian DPR RI. 13-18.

Ticoalu, S. S. (2013). Tanggung Jawab Pemerintah dalam Memberikan Pelayanan Kesehatan terhadap Masyarakat. Jurnal Lex et Societatis, I(5). 154-163.

Wahyudi, M. Z. (2009). Menjaga Pemilu tetap Luber Jurdil. Harian Kompas. 7. 
Widadio, N. A. (September, 2020). “316 Bakal Paslon Kepala Daerah Langgar Protokol Kesehatan Covid-19", aa.com Online, September 7, 2020, accessed from https://www.aa.com.tr/id/nasional/316-bakal-paslonkepala-daerah-langgar-protokol-kesehatan-covid-19/1965019. 


\section{ABOUT AUTHOR(S)}

Fathul Hamdani, born in West Lombok, West Nusa Tenggara on August 17, 1998, is a student of the Faculty of Law, University of Mataram. Served as a member of the Advocacy Department of BEM FH UNRAM in 2017, joined in the Reasoning and Research Student Activity Unit of the University of Mataram (UKM PRIMA UNRAM) from 2018 until now, Has served as Chair of the Constitutional Review Student Forum, Faculty of Law, University of Mataram in 2019, as a delegate in the Asean Youth Leader Excursion Malaysia-Singapore activity in 2019, and in early 2021 he founded a community called "Bale Aksara" which is engaged in developing rural community literacy, especially village children.

Ana Fauzia, born in Pasuruan, November 8, 1999 is a student of the Faculty of Law, University of Muhammadiyah Malang. Currently serving as Chair of the Research and Debate Community of FH UMM, and also the Ambassador of the 2020 Platinum Skills Achievement Student. In 2019 he was chosen as the Best Intelligence of International Woman Conference organized by the United Nations in Malaysia, then selected as a delegate in the Asean Youth Leader Excursion activity. Malaysia-Singapore. He is also active as a speaker in seminars and conferences, one of which is as a speaker at the International Conference on Law and Human Rights Event Organized by the Indonesian Ministry of Law and Human Rights. 